\title{
Relationships between Power Sources, Psychological Empowerment, School Culture and Psychological Climate: A Structural Equation Modeling
}

\author{
Dr. Pinar Mert (Academic) \\ Istanbul Sabahattin Zaim University-Turkey \\ pinar.mert@izu.edu.tr
}

\author{
Dr. Mustafa Özgenel (Academic) \\ Istanbul Sabahattin Zaim University-Turkey \\ mustafa.ozgenel@izu.edu.tr
}

\begin{abstract}
:
This research was carried out to make an inference about school managers' power sources, school culture, and psychological climate, which are thought to affect psychological empowerment will be emphasized. This study was designed and conducted according to the correlation research pattern to test the proposed conceptual model; and, this model has been tested with the Structural Equation Model (SEM). 358 teachers (252 women and 97 men) participated in the study. Then to evaluate the model $\chi^{2}$ (Chi-square), $\chi^{2} / d f$ ratio (Chi-square/degree of freedom), SRMR (Standardized root mean square residual), GFI (Goodness-of-fit index), AGFI (Adjusted goodness-of-fit index), NFI (Normed Fit Index), TLI (Turker-Lewis Index), CFI (Comparative Fit Index) and RMSEA (Root mean square error of approximation) are examined. According to the results, some hypotheses have been accepted but some of them not. $\mathrm{H} 1$-School principal's power sources affect psychological empowermentand $\mathrm{H} 2$-Power sources affect the psychological climate- have been rejected. However $\mathrm{H} 3$-School culture has an impact on its psychological climate-, H4 -Power sources affect school culture-, H5 -Psychological climate affects psychological empowermentand $\mathrm{H} 6$-School culture affects psychological empowerment- has been accepted.
\end{abstract}

Keywords: Psychological empowerment, school culture, psychological climate, power soures 


\section{INTRODUCTION}

Psychological empowerment is very important for both employees and managers. Employees realize their potential thanks to psychological empowerment and increase their effectiveness. Managers, together with their employees whose psychological well-being is at the highest level, achieve the targeted objectives of the organization. There are many studies that reveal that psychological empowerment has positive consequences for the benefit of the organization. Researches suggest that, thanks to psychological empowerment, employees are more committed to their institutions (Avolio, Zhu, Koh, and Bhatia, 2004; Liden, Wayne, and Sparrowe, 2000) and more productive (Martin and Bush, 2006). However, it is seen in the literature that studies to determine the preliminary variables affecting psychological empowerment have not been done much. In this study, school managers' power sources, school culture and psychological climate, which are thought to affect psychological empowerment will be emphasized.

Russell (1938) stated that one of the most basic concepts in social sciences is "power". Although leaders' attitudes differ from each other, the power distance is very wide in some societies. Turkey and the Far East countries' workers want their managers to appear strong, and they expect the task to have been dictated to them. French and Raven (1959) mention on five sources of power; reward power, coercive power, legitimate power, charismatic power, expert power (Lee and Low, 2009, p. 62).

Reward power is that individuals who will want rewards comply with the wishes of the manager. The coercive power is related to the situation of punishment when managers' orders and requests are not followed or undesirable behavior is displayed. Legitimate power is the ability of the manager to make certain requests and influence them thanks to his position. Charismatic power is the power to identify with their subordinates by influencing them, In expert power, managers are accepted thanks to their superior knowledge and skills (Lee and Low, 2009, p. 64).

Expert, charismatic, informational and loyalty power sources are included in the soft power group. Soft power sources emerge in administrative environments where task-oriented and personal qualities are dominant, and the use of a gentle and friendly language in a manner that will create sympathy in the subordinates is in the foreground. Reward power is included in the coercive power type and mutual power type harsh power sources group. Harsh power sources are mostly seen on authority and in top-down communication environments, and threatening language is used to ensure the harmony of subordinates (Aslanargun, 2009).

School culture is displays habits, traditions and formalities and is often referred to as organizational culture positioned in the educational background (Schoen \& Teddlie, 2008) Also, it shapes teacher-student interacts as well as interacts among teachers (Powers, 2009). While the power sources used by administrators affect school culture, school culture affects the power sources used by administrators too. Therefore, school managers must first understand the school's culture and then manage it. Culture is complex which has a very unique and idiosyncratic way of working. When an organization has a clear culture will ensure that things work well. Successful school principals know the important role that organizational culture plays in developing a successful school (Mac Neil, Prater and Busch, 2009). According to Balcı (1993), for school success, first of all, a culture should that values academic success, has highperformance expectations and prioritizes the establishment of collaborative relationships.

In this research, four sources of school cultures will be mentioned. These are supportoriented culture, success-oriented culture, task-oriented culture, and bureaucratic culture. The culture of support-oriented is based on human relationships and trust. There are mutual relationships and commitment among the members of the organization (Kilian 1999; Pheysey, 1993; Saphier and King, 1985). Success-Oriented Culture: The realization of the goals comes to the forefront than the rules. It is important to take individual responsibility. Organizations 
support and care for individual success (Pheysey 1993; Cooke and Szumal, 1993). Task-Oriented Culture: Organizational goals are ahead of individual goals. These types of organizations are business-centered organizations (Handy, 1981; Harrison, 1972). Bureaucratic Culture: It is a rational and centralized structure with strict rules and regulations, specialization and hierarchical authority is important (Can, Aşan and Aydın, 2006).

Information about the work of the employees in the organization and competence until today, psychological and social competence and capacity gained importance. In this context, organizations face more and more psychological empowerment concept day by day. Psychological empowerment can be defined as an active motivational orientation with regard to the individual's work role and an individual's feeling of being in control at work (Boudrias, Morin and Lajoie, 2014).

Psychological empowerment is dimensioned by Thomas and Velthouse (1990) in the form of competence, significance, choice, and influence. However, Spreitzer (1995) later revealed dimensions in terms of meaning, adequacy, autonomy, and influence, and a measurement tool related to these dimensions was developed. Meaning is the sense of understanding that the work or purpose of the employees is important according to their standards and values. Competence is the belief in the competence of employees to perform their duties skillfully (Spreitzer, 1995; Thomas and Velthouse, 1990).

Autonomy is the freedom to choose to perform their duties as they wish, employees perceive that they are autonomous in the process of starting and finishing work (Bell and Staw, 1980; Deci, Connel and Ryan, 1989; Zhang, Song, Tsui and Fu, 2014) and influence is related to the feeling that it has any effect on organizational results (Ashforth, 1989; Kirkman \& Rosen, 1999; Spreitzer, 1995). Psychological empowerment plays an important role in job satisfaction and organizational citizenship behavior (Wang, 2015).

Another concept related to psychological empowerment is the psychological climate. Organizational climate and psychological climate are concepts that are often confused with each other. They proposed that psychological climate was an individual attribute, whereas organizational climate was a situ- ational attribute of the organization (James and Jones, 1974).

The psychological climate is how the organization is perceived by its own employees (Barkhi and Kao, 2011, James and James 1989) and more individual assessment of conditions (Barkhi and Kao, 2011; Day and Bedeian, 1991; Zohar and Luria, 2004). In other words, the psychological climate is the personal and acquired cognitive descriptions that individuals place on their work environments (James and Sells, 1981). Schyns, Veldhoven and Wood (2009) suggest that psychological climate is a stronger variable than the organizational climate in predicting individual outcomes.

Researchers have made different classifications regarding the dimensions of the psychological climate. According to Koys and DeCotiis (1991) autonomy, trust, integrity, oppression, support, affirmation, justice, and innovation; Brown and Leigh (1996) management support, role clarity, perceived contribution and approvement, self-expression and professional difficulty; O'Neill and Arendt (2008) trust, autonomy, self-expression, organizational structure, and pressure; Amenumey and Lockwood (2008) facilitating work, customer orientation, feedback on performance, role clarity, internal service, managerial practices, and communication; Manning (2010) executive support and facilitation, job standards and in-service training, organizational rules-pressure, cooperation between the working group, spirit and friendship, conflict, and standards and goals.

\section{Effects of Power Sources on Psychological Empowerment}

Researches show that the power sources used by managers affect the attitudes, behaviors, and responses of the employees, thus organizational efficiency and performance (Atmaca, 2014; Altınkurt and Yılmaz, 2014; Özcan, Çağlar, Karataş and Polat, 2014; Yılmaz and Altınkurt, 2012), that reward power used by managers is the type of power that affects organizational culture the most (Koşar, 2008); legitimate power and charisma power have a 
positive effect on emotional commitment (Erkutlu and Chafra, 2013), and the sources of organizational power applied by school principals have a significant effect on teachers' organizational commitment levels (Akgül, 2013; Cömert, 2014; Jahangir, Akbar and Begum, 2006; Rahim and Afza, 1993).

Also, Toytok and Uçar (2018) stated that employees' perceptions of depression decreased when they used soft power sources When managers show positive attitudes and behaviors towards their employees, employees will also have positive attitudes towards their managers and organizations (Rhoades, Eisenberger and Armeli, 2001). It can be said that when school administrators use charismatic, expertise, informational and loyalty power sources, teachers will feel stronger in the school environment and this situation may have a positive effect on their performance.

Social Exchange Theory (Blau, 1964) talks about the relationship between psychological empowerment and manager's power sources. According to the theory, interpersonal relations are mutually interdependent, not only economically but also the whole interactions that produce psychological and social obligations (Karagonlar, Öztürk and Özmen, 2015). There are many studies in the literature explaining the relationship between managers and employees with the theory of social exchange (Ateş, 2017; Cropanzano and Mitchell, 2005; Yıldız and Yıldız, 2015). Based on all these results, it is foreseen that power sources of managers will have an effect on psychological empowerment.

$\mathrm{H}_{1}$ School principal's power sources affect psychological empowerment.

\section{Effects of Power Sources on Psychological Climate}

Çalışkur (2015) has worked on the concept of power and organizational psychology. As a result of the research, it stated that managers and employees have affected by the perceived social power within the organization. Akdemir (2017), has shown that there is a positive relationship between managerial power sources (charismatic power, legitimate power, reward power and expert power) and organizational structure that forms the organizational climate dimensions, individual responsibility, reward, risk-taking,

When the literature is examined, it is seen that there are very few studies on the relationship between power sources and psychological climate. On the other hand, there are studies on power sources and organizational climate. While organizational climate refers to employees' collective perception of the work environment, psychological climate refers to individual evaluations (Joyce \& Scolum 1982). Therefore, psychological climate and power sources are thought to be related to the results of research on power sources and organizational climate.

$\mathrm{H}_{2}$ Power sources affect the psychological climate

\section{The effect of school culture on psychological climate}

Different researchers found that there is a low, positive and significant relationship between the perceptions of classroom teachers and their school culture perceptions (Gligorovic and Buha, 2016; Kadıoğlu Ateş and Vatansever Bayraktar, 2018). Also, there is a moderate and significant relationship between their perceptions of school culture and their motivations. (Arpaguş 2011; Yılmaz 2009).

The psychological climate has been associated with various organizational behaviors. These; information sharing (Kettinger, Li, Davis and Kettinger, 2015), commitment to work (Altunkese, 2002; Brown and Leigh, 1996; Kahn, 1990), decision-making performance (Barkhi and Kao, 2011), organizational citizenship behavior (Altunkese, 2002; Ghanbari, Siroos and Eskandari, Asghar, 2014; Wei, Yu-Chen, Han, Tzu-Shian and Hsu, I-Chieh, 2010) business integration and job satisfaction (Biswas, 2010), organizational commitment (Thayer, 2008), psychological empowerment (Amenumey and Lockwood, 2008), adaptation to change (Martin, Jones and Callan, 2005), conflict management strategies (Strutton, Pelton and Lumpkin, 1993), job 
performance (Brown and Leigh, 1996; Biswas and Varma, 2007), business orientation (Day and Bedeian, 1991) and motivation (James, Hartman, Stebbins and Jones, 1977).

Rice and Steele (2004) found that there is a significant relationship between individuals' psychological well-being and culture. They stated that the group with the highest relationship was Scandinavian people. From this point of view, it is predicted that individuals are affected and can affect too, by the community they work in, as well as mutually.

$\mathrm{H}_{3}$ School culture has an impact on the psychological climate.

\section{The effect of power sources used by administrators on school culture}

Differences between school climate and culture are highlighted in organizational studies. Often the climate is viewed as behaviour, while culture is seen as comprising the values and norms of the school or organization (Hoy, 1990; Heck and Marcoulides 1996). Lunenburg and Ornstein (2004) described organizational climate as the total environ-mental quality within an organization and believe that the recent attention to the effectiveness of public schools and their cultures has shed more interest on the importance of climate. The relationship between culture and climate was supported by Schein $(1985,1996)$ when he stated that norms, values, rituals and climate are all manifestations of culture. In addition, the relation- ship of culture and climate is further supported by McDougall and Beattie (1998), as well as by the early studies of Schneider and Reichers (1983).

Findings obtained from the researches show that organizational climate is positively and moderately correlated with all dimensions of instructional leadership (Ayık and Şayir 2014). Transformational leadership has an impact on school climate's commitment, resource adequacy, professional interest and innovation dimensions, and interactive leadership's participatory decision-making dimension. Also, it has been found that it has an impact on the leadership behavior of school principals (Tajasom and Ahmad, 2011) and the school climate (Şentürk and Sağnak 2012). Lastly, the reward power used by school administrators is the type of power that most affects the organizational culture (Koşar, 2008).

Differences between school climate and culture often mentioned in organizational studies. The climate is viewed as behaviour but culture is seen as comprising the values and norms of the school or organization (Hoy 1990; Heck and Marcoulides 1996). McDougall ve Beattie (1998), Schneider and Reichers (1983) stated that there is a relationship between organizational climate and organizational culture. Also, a study on elementary schools showed that principals could indirectly affect school effectiveness by influencing the school's culture (Hallinger, Bickman and Davis, 1996). Based on these studies, it has been predicted that the power sources used by the leaders may affect the school culture.

$\mathrm{H}_{4}$ Power sources affect school culture.

\section{The effect of psychological climate on psychological empowerment.}

In their research on academic staff working in public hospitals, Gül and Çöl (2004) found that empowered employees showed emotional and normative commitment to their organizations. Mutual trust has an important place in psychological empowerment. Employees who are trusted by the work community will feel a sense of safety and acceptance. In this way, they focus more on their duties (Doğan, 2006). Because, strengthening can be positively and negatively affected by environmental factors (Ghani and Hussin, 2009). Thomas and Velthouse (1990) stated that psychological empowerment can be increased by changing the psychological climate. Therefore, it is predicted that the psychological climate may affect psychological empowerment.

$\mathrm{H}_{5}$ Psychological climate affects psychological empowerment.

\section{The effect of school culture on psychological empowerment}

Psychological empowerment positively affects work performance (Chen, 2011; Kanbur, 2018); organizational commitment (Bogler and Someck, 2004; Çekmecioğlu and Eren, 2007) and 
job satisfaction (Tolay, Sürgevil and Topoyan, 2012). It improves internal and external motivation (Ihtiyaroğlu, 2017) and reduces burnout (Polatcı and Özçalık, 2013).

Spreitzer (1995) argues that empowered employees see themselves as competent and able to influence their jobs and work environments in meaningful ways. Get Liden et. (2000) stated that employees who find their job meaningful and who have high motivation affect their work environment and they are affected by their work environment. Based on all these research results, it is thought that employees who strengthen their performance with psychological empowerment may have an impact on creating a strong school culture.

$\mathrm{H}_{6}$ School culture affects psychological empowerment.

Based on the hypotheses put forward theoretically, it was produced the conceptual model given in Figure 1.

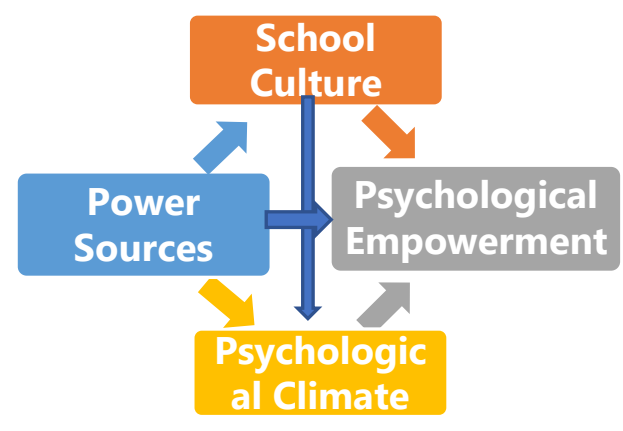

Figure 1. Conceptual model
According to the conceptual model given in Figure 1;

Power sources affect school culture, psychological climate and psychological empowerment.

$\checkmark$ School culture affects psychological empowerment.

$\checkmark$ School culture affects the psychological climate.

$\checkmark$ The psychological climate affects psychological empowerment.

\footnotetext{
Also;

$\checkmark$ Power sources and school culture together affect the psychological climate,

$\checkmark$ Power sources and psychological climate together affect psychological empowerment,

$\checkmark$ School culture and psychological climate together affect psychological empowerment,

$\checkmark$ Power sources school culture, and psychological climate together affect psychological empowerment.
}

\section{METHOD}

\section{Research Model}

This study was designed and conducted according to the correlation research pattern to test the conceptual model proposed in Figure 1. The correlation research pattern has two purposes. The first describes the degree and direction of the relationship between two or more variables. The second purpose is to estimate the change of the independent variable on the dependent variable if there is a sufficiently large relationship between the two variables (Fraenkel \& Wallen, 2006). Creswell (2017) defines this research pattern as a predictive screening pattern. According to Creswell, the predictive research pattern is the research pattern made to "predict future behavior and determine the variables that will predict the outcome". In this study, a conceptual model was proposed to explain the relationships between dependent and independent variables, and this model, which was collected by data, was tested in the Structural Equation Model (SEM-SEM). The structural equation model tests the suitability of the data obtained by the researcher with the conceptual theoretical model (Özgenel, 2018). 


\section{Sample data collection}

The study data were collected in 2020 by teachers working in various public schools in the Anatolian side of Istanbul, using the method of "easy sampling". Before the study, the purpose of the research was explained, the approval of the participants was obtained, and the privacy of the participants was protected. In the research, 500 scale forms were distributed, 381 scales were returned, 32 scale forms were not included in the analysis because they were missing, incorrect, or empty.

$72.2 \%$ (252) of the teachers participating in the study are women and $27.8 \%(97)$ are men. While the majority of the participant teachers are between the ages of $31-40$ (49.9\%), the average seniority is in the range of $11-15$ years (34.1\%). $87 \%$ of the teachers are undergraduate graduates and $12.9 \%$ are graduate graduates. $26.1 \%$ (91) of the teachers work in primary school, $46.4 \%$ (162) secondary school, and $27.5 \%$ (96) work in high school.

\section{Measures}

In the research, 4 different scales were used together with the Information Form. All the scales were developed or adapted for educators.

Psychological Climate Scale (PCS) was developed by Brown and Leigh (1996) and adapted to Turkish by Argon and Limon (2017). The original form of the scale has six sub-dimensions and 21 items. The original scale is in a 7-point Likert style. However, while the scale was adapted to Turkish, it was used as a 5-point Likert. The scale options are from "Strongly Disagree-1" to "Strongly Agree-5 In the adaptation study, the items belonging to the sub-dimensions of "Organizational Contribution" and "Organizational Approval", which are two different factors in the original scale, were collected under one factor. The vocational difficulty factor did not meet the reliability criteria and removed from the scale. In the adaptation study, the scale was found to consist of 4 factors and 19 items. The item distribution in the scale is "Supportive Management (1-6 items), Organizational Contribution and Approval (7-12 items), SelfExpression (13-16 items), Role Significance (17-19 items)". Total scores are obtained by summing up all the items from the scale. Adaptation studies to Turkish were carried out on teachers. (Argon \& Limon 2017)

School Culture Scale (SCS) was developed by Terzi (2005). Terzi determined 4 cultural dimensions with a scale of 29 items in schools. These cultural dimensions are Support-oriented culture $(7,10,11,16,18,24,26,27)$, Success-oriented culture $(9,17,21,22,25,28)$, Bureaucratic Culture $(8,12,13,14,15,19,20,3,29)$, Task-oriented Culture (1, 2, 3, 4, 5, 6). School Culture Scale is rated as 5-point Likert (1-Never 2-Rarely 3-Sometimes 4-Mostly 5-Always). Ölçekten toplam puan elde edilmemektedir. Total score is not obtained from the scale. Instead, each cultural dimension item is collected and a total score or arithmetic average is obtained. There are no inverse items on the scale.

Power Sources Scale (PSS) was developed by Aslanargun (2009). The scale consists of 30 items and 7 dimensions. The Power Sources Scale has two basic dimensions (soft and harsh). In the scale, reward (1-5 items), coercive (6-10 items) and response (11-16 items) power sources; sources of expertise (17-21 items), informational (22-24 items), loyalty (25-28 items) and charismatic (28-30 items) are classified as soft power sources. The scale was scored as "Always (5), Mostly (4), Sometimes (3), Rarely (2) and Never (1)". Scale sub-dimensions can be summed as well as soft and harsh power sources can be obtained as total points. There are no inverse items in the scale.

Psychological Empowerment Scale; 4-dimensional and 12-item (Meaning 1-3, proficiency 46, autonomy 7-9, and effect 10-12) measurement tool were developed by Spreitzer (1995). Surgevil, Tolay, and Topoyan (2013) adapted to Turkish. There are three expressions in each dimension. While the sub-dimensions of the scale are evaluated within themselves, results can be obtained for each dimension, and the total psychological empowerment score is obtained by adding all dimensions. The psychological empowerment scale was rated with a 5-point Likert Scale. Accordingly, participants were asked to indicate their level of participation in statements 
about psychological empowerment by marking one of the options: "1-Strongly disagree, 2Disagree, 3-Neither agree or disagree, 4-Agree, 5-Strongly agree". The specified high values; indicates a high perception of psychological empowerment. There are no inverse items in the scale.

\section{Data analysis}

To measure the reliability of the scales used in the study, Cronbach Alpha; coefficient, kurtosis and skewness values were calculated for the normality assumption. Percentage and frequency tests were used to describe the data of the personal characteristics of the participants. Scoring of the statements in the scale; never between 1-1.79; rarely between 1.80-2.59; sometimes between 2,60-3,39; mostly between 3.40-4.19 and always 4.20-5.00.

Structural Equation Model (SEM) was used to test the conformity of the conceptual model to the data and to examine the relationships between the variables. In order to evaluate the model, first of all, correlation coefficients between variables were examined, whether the road coefficients were significant was checked, and related and not significant road coefficients were removed from the model. Then to evaluate the model $\chi^{2}$ (Chi-square), $\chi^{2} / \mathrm{df}$ ratio (Chisquare/degree of freedom), SRMR (Standardized root mean square residual), GFI (Goodness-offit index), AGFI (Adjusted goodness-of-fit index), NFI (Normed Fit Index), TLI (Turker-Lewis Index), CFI (Comparative Fit Index) and RMSEA (Root mean square error of approximation) are examined.

Table 1. The kurtosis, skewness and reliability values of the scales

\begin{tabular}{lcccc}
\hline Variables & N & Skewness & Kurtosis & Cronbach Alpha a \\
\hline Psychological Empowerment (PE) & 349 & -.756 & 1.490 & .891 \\
Harsh power Sources (HPS) & 349 & .672 & .804 & .785 \\
Soft power Sources (SPS) & 349 & -.073 & -.992 & .965 \\
Psychological Climate (PC) & 349 & -.052 & .626 & .855 \\
Support-Oriented Culture(SUPOC) & 349 & -.420 & 1.301 & .861 \\
Success-Oriented Culture(SUCOC) & 349 & -.279 & .461 & .825 \\
Bureactatic Culture (BUC) & 349 & -.026 & .700 & .784 \\
Task-Oriented Culture (TOC) & 349 & -.465 & .700 & .773 \\
\hline
\end{tabular}

As can be seen in Table 1, it is seen that the kurtosis and skewness values are between 1.5 and +1.5 , and the reliability coefficients are above .70 . Considering these values, it can be said that the data are suitable for the SEM analysis designed for the purpose of the research.

The conceptual model has been evaluated according to the criteria suggested in the fit indices given in Table 2 (Barret, 2007, Bentler and Bonett 1980; Byrne, Shavelson and Muthen, 1989; Hu and Bentler, 1999; Jöreskog, 2004; Kline, 2011; Maydeu-Olivares and Garcı'a-Forero, 2010; Schermelleh-Engel, Moosbrugger and Müller, 2003; Schumacker and Lomax, 2010).

Table 2.

Model evaluation fit indices and criteria

\begin{tabular}{lcc}
\hline Index & Perfect Fit & Acceptable Compliance \\
\hline$\chi^{2} / \mathrm{df}$ ratio & $0 \leq \chi^{2} / \mathrm{df}<2-3$ & $3<\chi^{2} / \mathrm{df} \leq 5$ \\
GFI & $.95 \leq \mathrm{GFI} \leq 1.0$ & $.90 \leq \mathrm{GFI}<95$ \\
$\mathrm{AGFI}$ & $.90 \leq \mathrm{AGFI} \leq 1.0$ & $.85 \leq \mathrm{AGFI}<.90$ \\
$\mathrm{NFI}$ & $.95 \leq \mathrm{NFI} \leq 1.0$ & $.90 \leq \mathrm{NFI}<.95$ \\
$\mathrm{TLI}$ & $.95 \leq \mathrm{TLI} \leq 1.0$ & $.90 \leq \mathrm{TLI}<.95$ \\
$\mathrm{CFI}$ & $.95 \leq \mathrm{CFI} \leq 1.0$ & $.90 \leq \mathrm{CFI}<.95$ \\
RMSEA & $0 \leq \mathrm{RMSEA} \leq .05$ & $.05<\mathrm{RMSEA} \leq .08$ \\
SRMR & $0 \leq \mathrm{SRMR} \leq .05$ & $.05<\mathrm{SRMR} \leq .08$ \\
\hline
\end{tabular}




\section{RESULTS}

Correlation analysis was carried out to determine the pattern of relations between the variables in the study.

As it can be seen in Table 3, there is a negative and low level significant relationship between psychological empowerment and harsh power sources $(r=.129 ; p<.01)$. Also, there is a positive significant relationship between psychological empowerment with soft power sources $(r=.202 ; p<.01)$, psychological climate $(r=.478 ; p<.01)$, support-oriented culture $(r=.403 ; p<.01)$, success-oriented culture $(r=.420 ; p<.01)$ and task-oriented culture $(r=.385 ; p<.01)$. However, there is no significant relationship between psychological empowerment and bureaucratic culture $(r=-.035 ; p>.05)$.

There is a positive relationship between harsh power sources and soft power sources $(r=-$ . 516; $p<.01)$, and psychological climate $(r=.117 ; p<.05)$. Likewise, there is a positive relationship support-oriented culture $(r=.133 ; p<.05)$, success-oriented culture $(r=.115 ; p<.05)$, bureaucratic culture $(r=.120 ; p<.05)$. However, it is observed that there is a negative relationship between task-oriented culture $(r=.142 ; p<.01)$.

Table 3. Correlation analysis results

\begin{tabular}{|c|c|c|c|c|c|c|c|c|c|c|c|}
\hline & $N$ & Mean & $S D$ & 1 & 2 & 3 & 4 & 5 & 6 & 7 & 8 \\
\hline $\begin{array}{l}\text { 1-Psychological } \\
\text { Empowerment (PE) }\end{array}$ & 349 & 4.199 & .515 & 1 & & & & & & & \\
\hline $\begin{array}{l}\text { 2-Harsh Power } \\
\text { Sources (HPS) }\end{array}$ & 349 & 2.844 & .355 & $-.129^{* *}$ & 1 & & & & & & \\
\hline $\begin{array}{l}\text { 3-Soft power } \\
\text { Sources (SPS) }\end{array}$ & 349 & 3.313 & .968 & $.202^{* *}$ & $-.516^{* \star}$ & 1 & & & & & \\
\hline $\begin{array}{l}\text { 4-Psychological } \\
\text { Climate (PC) }\end{array}$ & 349 & 3.779 & .417 & $.478^{* *}$ & $-.117^{*}$ & $.279^{* *}$ & 1 & & & & \\
\hline $\begin{array}{l}\text { 5-Support-Oriented } \\
\text { Culture (SUPOC) }\end{array}$ & 349 & 3.847 & .593 & $.403^{* *}$ & $-.133^{*}$ & $.365^{* *}$ & $.665^{* *}$ & 1 & & & \\
\hline $\begin{array}{l}\text { 6-Success-Oriented } \\
\text { Culture (SUCOC) }\end{array}$ & 349 & 3.879 & .610 & $.420^{* *}$ & $-.115^{*}$ & $.346^{* *}$ & $.686^{* *}$ & $814^{* *}$ & 1 & & \\
\hline $\begin{array}{l}\text { 7-Bureactatic Culture } \\
(B \cup C)\end{array}$ & 349 & 3.200 & .597 & -.035 & $.120^{\star}$ & $-.179^{\star \star}$ & .039 & -.043 & .022 & 1 & \\
\hline $\begin{array}{l}\text { 8-Task-Oriented } \\
\text { Culture (TOC) }\end{array}$ & 349 & 4.129 & .521 & $.385^{* *}$ & $-.142^{* *}$ & $.318^{* *}$ & $.561^{* \star}$ & $579^{* *}$ & $628^{\star \star}$ & $.154^{* *}$ & 1 \\
\hline
\end{tabular}

There is a positive relationship between soft power sources and psychological climate $(r=$ 279; $p<.01)$. Likewise, there is a positive relationship between support culture $(r=.365 ; p<.01)$, success culture $(r=.346 ; p<.01)$ and task culture $(r=.318 ; p<.01)$. However, it is observed that there is a negative relationship with bureaucratic culture $(r=-.179 ; p<.01)$.

After determining the relationships between the variables, the conceptual model was tested with the collected data. First, the conceptual model was added sequentially and analyzed gradually. 


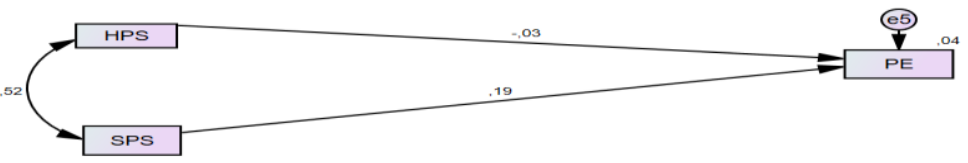

HPS: Harsh Power Sources; SPS: Soft Power Sources; PE: Psychological Empowerment

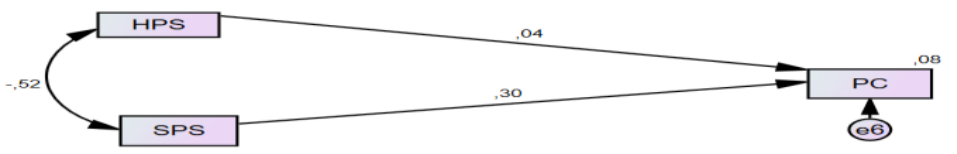

HPS: Harsh Power Sources; SPS Soft Power Sources; PC: Psychological Climate

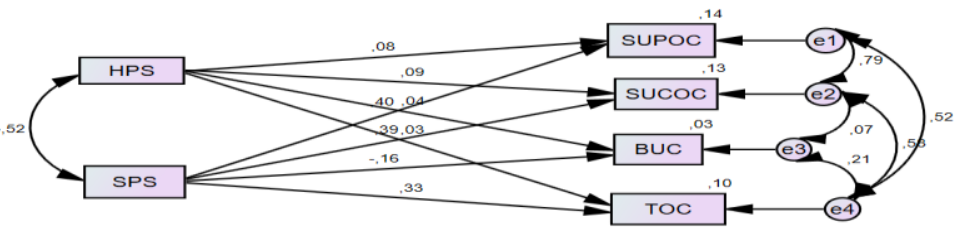

HPS: Harsh Power Sources; SPS Soft Power Sources; SUPOC:

Support-Oriented Culture; SUCOC; Success-Oriented Culture; BUC: Bureactatic Culture; TOC: Task-Oriented Culture
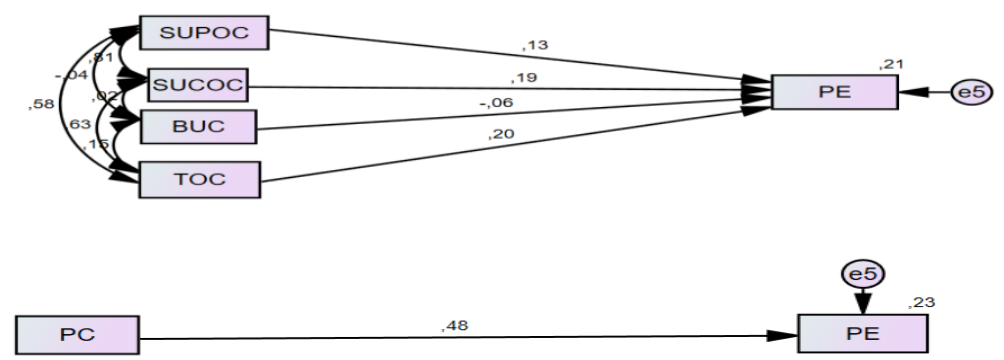

PC: Psychological Climate; PE: Psychological Empowerment

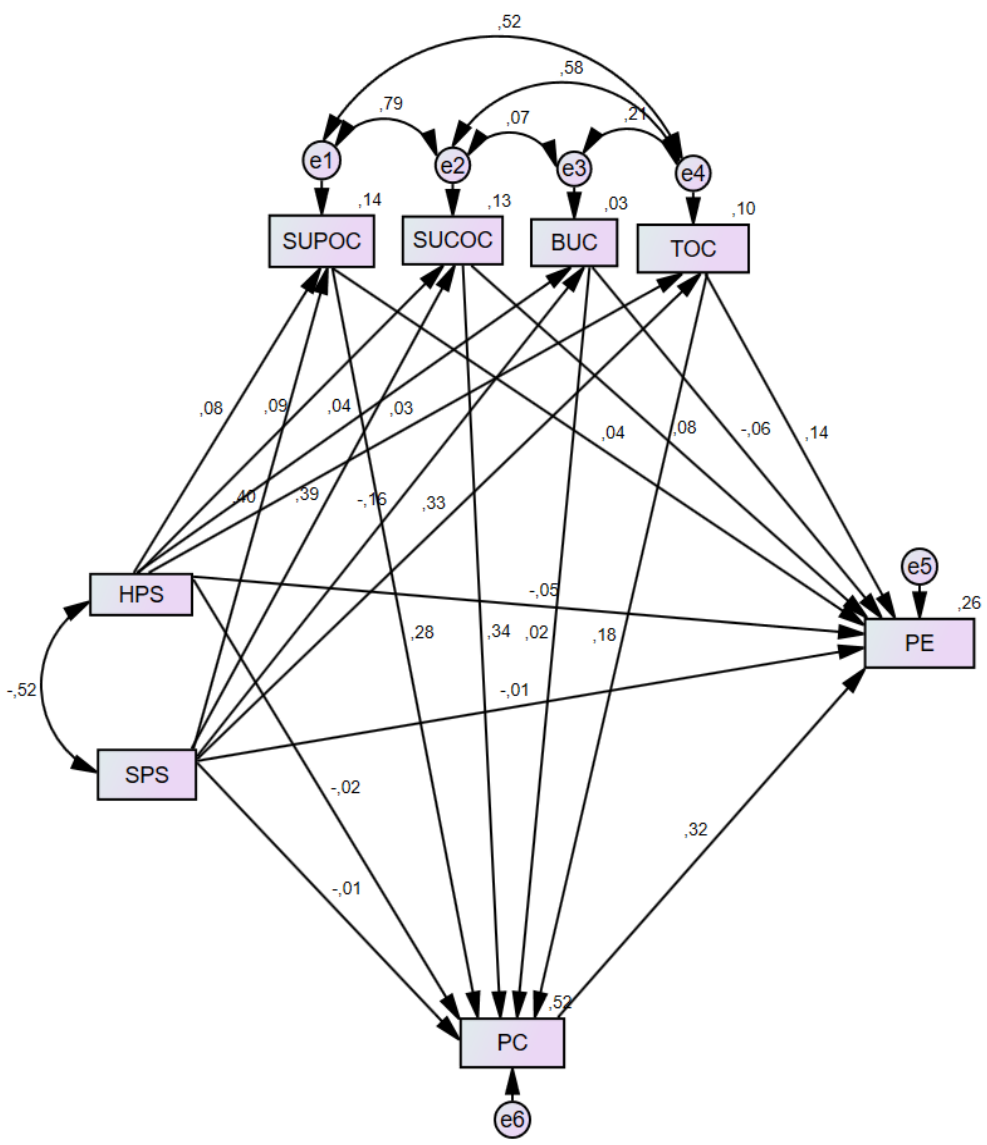

HPS: Harsh Power Sources; SPS: Soft Power Sources; SUPOC: Support-Oriented Culture; SUCOC; SuccessOriented Culture; BUC: Bureactatic Culture; TOC: Task-Oriented Culture; PC: Psychological Climate; PE: Psychological Empowerment

Figure 2. Relationships between variables in the conceptual model 
The fit indexes of the conceptual model given in Figure 2 are given in Table 4 .

Table 4. Conceptual model fit indexes

\begin{tabular}{lccccccccccc}
\hline & $\boldsymbol{\chi}^{\mathbf{2}}$ & $\boldsymbol{d f}$ & $\boldsymbol{p}$ & $\boldsymbol{\chi}^{\mathbf{2} / \boldsymbol{d} \boldsymbol{f}}$ & SRMR & GFI & AGFI & NFI & TLI & CFI & RMSEA \\
\hline Mode & .174 & 1 & .676 & .174 & .005 & 1.000 & .995 & 1.000 & 1.021 & 1.000 & .000 \\
\hline $\begin{array}{l}\text { Achie' } \\
\text { ed Perfect } \\
\text { values }\end{array}$ & Fit & $\begin{array}{l}\text { Perfe } \\
\text { ct Fit }\end{array}$ & $\begin{array}{c}\text { Perfect } \\
\text { Fit }\end{array}$ & $\begin{array}{c}\text { Perfect } \\
\text { Fit }\end{array}$ & Perfect Fit & $\begin{array}{c}\text { Perfect } \\
\text { Fit }\end{array}$ & $\begin{array}{c}\text { Perfect } \\
\text { Fit }\end{array}$ & $\begin{array}{c}\text { Perfect } \\
\text { Fit }\end{array}$ & $\begin{array}{c}\text { Perfect } \\
\text { Fit }\end{array}$ & $\begin{array}{c}\text { Perfect } \\
\text { Fit }\end{array}$ & Perfect Fit \\
\hline
\end{tabular}

$\chi^{2}=$ Chi-square; $\mathrm{df}=$ degree of freedom; $\mathrm{p}<.05 ; \mathrm{SRMR}=$ Standardized root mean square residual; $\mathrm{GFI}=$ Goodness-of-fit index; AGFI=Adjusted goodness-of-fit index; NFI=Normed Fit Index; TLI=Turker-Lewis Index; $\mathrm{CFI}=$ Comparative Fit Index; RMSEA= Root mean square error of approximation.

According to Table 4, the conceptual model fit indices are at the perfect fit level. However, in order to accept the conceptual model, in addition to the chi-square and fit indices, the regression and correlation coefficients must be at least .05 level (Şimşek, 2007). The significance of regression and correlation coefficients besides the fit indices and chi-square value of the model supports model fit. The regression coefficients of the road relations of the conceptual model are given in Table 5 .

Table 5. Regression coefficients of the conceptual model

\begin{tabular}{|c|c|c|c|c|c|c|c|c|}
\hline & & & $r^{2}$ & S.E. & C.R. & $\mathbf{p}$ & Label & Standardized $r^{2}$ \\
\hline SUPOC & $<---$ & HPS & 126 & 097 & 1,302 & 193 & $x$ & ,076 \\
\hline SUCOC & $<---$ & HPS & ,148 & 100 & 1,479 & 139 & $x$ & ,087 \\
\hline BUC & $<---$ & HPS &, 063 & ,103 & ,607 &, 544 & $x$ & ,037 \\
\hline TOC & $<---$ & HPS &, 045 & ,087 &, 517 & ,605 & $x$ & ,031 \\
\hline SUPOC & $<---$ & SPS & 247 &, 036 & 6,946 & $* \star *$ & &, 404 \\
\hline SUCOC & $<---$ & SPS &, 246 & ,037 & 6,674 & $\star \star *$ & & 391 \\
\hline$B \cup C$ & $<---$ & SPS &,- 099 & ,038 & $-2,603$ & 009 & &,- 160 \\
\hline TOC & $<---$ & SPS & 180 &, 032 & 5,644 & $\star \star \star *$ & &, 335 \\
\hline PC & $<---$ & HPS &,- 024 & ,051 &,- 474 & ,635 & $x$ &,- 021 \\
\hline PC & $<---$ & SPS &,- 003 & ,020 &,- 137 & 891 & $x$ &,- 006 \\
\hline PC & $<---$ & SUPOC & 198 &, 046 & 4,321 & 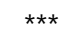 & & ,282 \\
\hline PC & $<---$ & SUCOC &, 236 &, 046 & 5,105 & $* \star \star$ & & ,345 \\
\hline PC & $<---$ & $B \cup C$ &, 012 & 027 & ,458 & ,647 & $x$ & ,018 \\
\hline PC & $<---$ & TOC & 142 &, 040 & 3,566 & $\star * *$ & & 177 \\
\hline PE & $<---$ & HPS &,- 080 & ,078 & $-1,017$ & 309 & $x$ &,- 055 \\
\hline PE & $<---$ & SPS &,- 007 & ,031 &,- 225 & ,822 & $x$ &,- 013 \\
\hline PE & $<---$ & SUPOC & ,033 & ,073 & ,453 & 650 & $x$ & ,038 \\
\hline PE & $<---$ & SUCOC & ,071 & ,074 & 963 & ,336 & $x$ & ,084 \\
\hline PE & $<---$ & BUC &,- 056 & ,042 & $-1,333$ & 183 & $x$ &,- 065 \\
\hline PE & $<---$ & TOC & 137 & ,062 & 2,199 & ,028 & & 138 \\
\hline $\mathrm{PE}$ & $<---$ & PC & ,393 & ,083 & 4,753 & $\star \star \star *$ & & ,317 \\
\hline
\end{tabular}

As seen in Table 5, the regression coefficients between some variables are not significant $(X)(p>.05)$. For this reason, the meaningless regression coefficients were deleted from the model in order from highest to lowest, and the analysis was renewed after each deletion. The measurement model obtained as a result of this modification is given in Figure 3. 


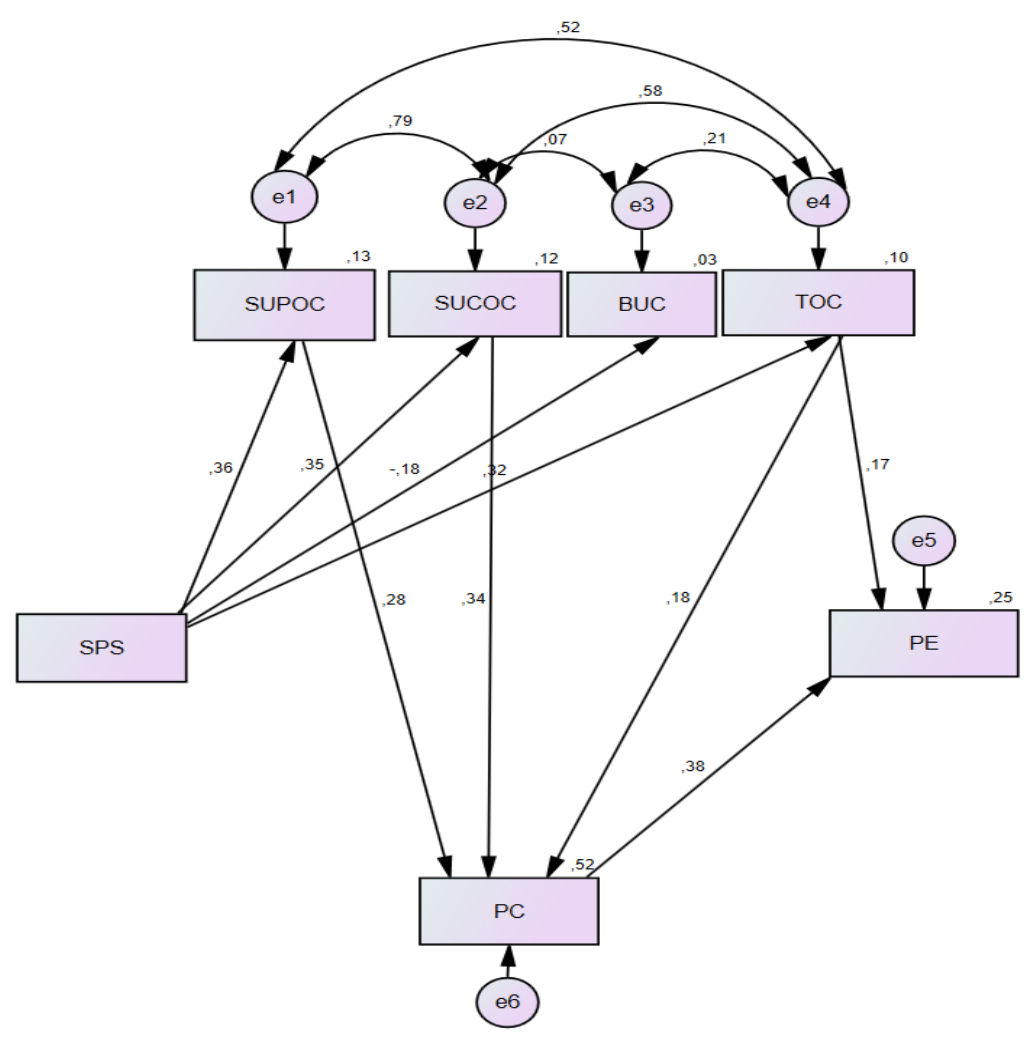

SPS: Soft Power Sources; SUPOC: Support-Oriented Culture; SUCOC: SuccessOriented Culture, BUC: Bureactatic Culture, TOC: Task-Oriented Culture, PC: Psychological Climate PE: Psychological Empowerment

Figure 3. Measurement model

The fit indices for the measurement model shown in Figure 3 are given in Table 6 .

Table 6. Measurement model fit indexes

\begin{tabular}{lccccccccccc}
\hline & $\boldsymbol{\chi}^{\mathbf{2}}$ & $\boldsymbol{d f}$ & $\boldsymbol{p}$ & $\boldsymbol{\chi}^{\mathbf{2} / \boldsymbol{d} \boldsymbol{f}}$ & SRMR & GFI & AGFI & NFI & TLI & CFI & RMSEA \\
\hline Model & 5.766 & 7 & .567 & .824 & .021 & .995 & .981 & .994 & 1.000 & 1.000 & .000 \\
\hline $\begin{array}{l}\text { Achieved } \\
\text { values }\end{array}$ & $\begin{array}{l}\text { Perfe } \\
\text { ct Fit }\end{array}$ & $\begin{array}{c}\text { Perfe } \\
\text { ct Fit }\end{array}$ & $\begin{array}{c}\text { Perfe } \\
\text { ct Fit }\end{array}$ & $\begin{array}{c}\text { Perfect } \\
\text { Fit }\end{array}$ & Perfect Fit & $\begin{array}{c}\text { Perfect } \\
\text { Fit }\end{array}$ & $\begin{array}{c}\text { Perfect } \\
\text { Fit }\end{array}$ & $\begin{array}{c}\text { Perfect } \\
\text { Fit }\end{array}$ & $\begin{array}{c}\text { Perfect } \\
\text { Fit }\end{array}$ & $\begin{array}{c}\text { Perfect } \\
\text { Fit }\end{array}$ & Perfect Fit \\
\hline
\end{tabular}

$\chi^{2}=$ Chi-square; $\mathrm{df}=$ degree of freedom; $\mathrm{p}<.05 ; \mathrm{SRMR}=$ Standardized root mean square residual; $\mathrm{GFI}=$ Goodness-of-fit index; $\mathrm{AGFI}=$ Adjusted goodness-of-fit index; NFI=Normed Fit Index; $\mathrm{TLI}=$ Turker-Lewis Index; $\mathrm{CFI}=$ Comparative Fit Index; RMSEA= Root mean square error of approximation.

When Table 6 is examined, it is understood that all fit indices of the measurement model show a perfect fit. After the fit indexes, it has been again checked whether the regression coefficients were significant and given in Table 7 .

When Table 7 is examined, it is seen that all the regression coefficients are significant $(p$ $<.05)$. According to the measurement model, soft power sources explain $13 \%$ of the total variance in the support-oriented culture, $12 \%$ of the total variance in the success-oriented culture. Also, it explains, $3 \%$ of the total variance in the bureaucratic culture, and $10 \%$ of the total variance in the task-oriented culture. Soft power sources together with support-oriented culture, success-oriented culture, and task-oriented culture explain $52 \%$ of the total variance in the psychological climate. Soft power sources and task-oriented culture, soft power sources and 
support-oriented culture, success-oriented culture, task-oriented culture, and psychological climate together explain $25 \%$ of the total variance of psychological empowerment.

Table 7. Regression coefficients of path relationships in the measurement model

\begin{tabular}{lllllllc}
\hline & & & $\mathbf{r}^{2}$ & S.E. & C.R. & $\mathbf{p}$ & ${\text { Standardize } \mathbf{r}^{2}}^{\text {S }}$ \\
\hline SUPOC & $<---$ & SPS &, 223 &, 031 & 7,307 & $* * *$ &, 365 \\
SUCOC & $<---$ & SPS &, 218 &, 032 & 6,881 & $* * *$ &, 346 \\
TOC & $<---$ & SPS &, 171 &, 027 & 6,277 & $* * *$ &, 319 \\
PC & $<---$ & SUPOC &, 196 &, 045 & 4,337 & $* * *$ &, 279 \\
PC & $<---$ & SUCOC &, 236 &, 046 & 5,114 & $* * *$ &, 345 \\
PC & $<---$ & TOC &, 146 &, 038 & 3,808 & $* * *$ &, 183 \\
BUC & $<---$ & SPS &,- 111 &, 032 & $-3,404$ & $* * *$ &,- 179 \\
PE & $<---$ & TOC &, 168 &, 056 & 3,033 &, 002 &, 170 \\
PE & $<---$ & PC &, 473 &, 069 & 6,824 & $* * *$ &, 383 \\
\hline
\end{tabular}

In other words, soft power sources affect the support-oriented culture, success-oriented culture, and task-oriented culture positively, while it affects the bureaucratic culture negatively. Soft power sources together with support-oriented culture, success-oriented culture, and taskoriented culture affect the psychological climate positively. Bureaucratic culture does not affect the psychological climate. Soft power sources and task-oriented culture, soft power sources and support-oriented culture, success-oriented culture, task-oriented culture, and psychological climate together have a positive effect on psychological empowerment.

According to these findings, whether or not conceptually hypotheses are admitted is given in Table 8.

Table 8. Acceptance-rejection status of hypotheses

\begin{tabular}{lcc}
\hline & Acceptance & Rejection \\
\hline $\mathrm{H}_{1}$ School principal's power sources affect psychological empowerment. & & $\mathrm{X}$ \\
$\mathrm{H}_{2}$ Power sources affect the psychological climate & $\mathrm{X}$ \\
$\mathrm{H}_{3}$ School culture has an impact on its psychological climate. & $\mathrm{X}$ \\
$\mathrm{H}_{4}$ Power sources affect school culture. & $\mathrm{X}$ \\
$\mathrm{H}_{5}$ Psychological climate affects psychological empowerment. & $\mathrm{X}$ \\
$\mathrm{H}_{6}$ School culture affects psychological empowerment. & $\mathrm{X}$ \\
\hline
\end{tabular}

According to Table 8, $H_{1}$ and $H_{2}$ hypotheses were rejected and $H_{3}, H_{4}, H_{5}$, and $H_{6}$ hypotheses were accepted.

\section{DISCUSSION AND CONCLUSION}

The purpose of this study is to determine the pattern of relationships between the sources of power used by school principals, school culture, and psychological climate, which are considered as the primary variables affecting the psychological empowerment of teachers in the school context. The conceptual model created for this purpose has been tested with the collected data. As a result of the first analysis:

- While soft power sources positively affect psychological empowerment; harsh power sources have no effect. 
- While soft power sources positively affect the cultures of task-oriented, successoriented, and support-oriented; it affects bureaucratic culture negatively. Harsh power sources do not affect the cultural dimensions of the school.

- While soft power sources positively affect the psychological climate; harsh power sources have no effect.

- While success-oriented culture and task-oriented culture have positive effects on psychological empowerment; bureaucratic culture and support-oriented culture do not affect psychological empowerment.

- While success-oriented culture, task-oriented culture, and support-oriented culture affect the psychological climate positively; bureaucratic culture does not affect.

- Psychological climate positively affects psychological empowerment.

However, when all the variables are added to the model, the power sources of school principals affect the psychological climate through school culture. Similarly, the power sources of school principals affect the psychological empowerment levels of teachers through both school culture and psychological climate. Because when power sources of school principals and school culture, psychological climate, and psychological empowerment are analyzed one by one, power sources affect variables different levels. However, when a strong variable such as a school culture that affects the entire functioning of the organization and employees is added to the model, the direct effect of power sources of school principals on psychological climate and psychological empowerment disappears. School principals' power psychological affect psychological climate and psychological empowerment through school culture. This result actually has proved to us once again how effective school culture is in the organization.

As a result of the research, the psychological of soft power (expertise, informational, loyalty, and charisma) affect the culture of support-oriented, culture of success-oriented and task-oriented positively and significantly, while negatively affecting the bureaucratic school culture. This result is predictable; because, in a school dominated by bureaucratic culture, a more central structure and a stiff hierarchy draw attention (Özdemir, 2012). Therefore, it can be said that the administrators who mobilize their teachers with their expertise or charismatic features do not need a prescriptive and strict structure inherent in the bureaucratic culture and this situation is reflected in the existing culture of the school.

According to another result of the research, soft power psychological such as informational, loyalty, expertise and charisma power does not directly affect the psychological climate and psychological empowerment This result is not compatible with other research findings in the literature. Because, the psychological climate is expressed as the whole of the attitudes and reactions related to the organization that the individual is in and the power psychological used by managers affect the attitudes, behaviors, and responses of the employees (Altınkurt, Yılmaz, Erol and Salalı; 2014; Atmaca, 2014, Özcan, Çağlar, Karataş and Polat, 2014; Yılmaz and Altınkurt, 2012). When the psychological climate perceived by teachers and the psychological of power used only by their administrators is examined, it is seen that the power sources affect the psychological climate, but when analyzed together with the school culture variable; it was observed that the power resources used by the manager did not affect the psychological empowerment of the teachers. The reason for this is that school culture is a very dominant variable and it affects psychological empowerment with its own dynamics by neutralizing the effects of the power resources used by the administrators when it comes into play.

In the research, support-oriented culture, success-oriented culture, and task-oriented culture positively affect the psychological climate. In schools where the culture of support is dominant, mutual respect, understanding, and cooperation are observed among the employees. (Sezgin, 2010; Özdemir, 2012). The focus of organizational behavior is the support given to the employees (Aydın, 2010). The basic element of educational organizations is human, in this case, 
it does not seem possible that the psychological climate consisting of individuals' opinions and feelings will not be effective in schools. If there is a developed culture of support, success, and duty in schools, it can be thought that this situation directly affects teachers' perception of the psychological climate.

Demir (2010) stated that the level of psychological empowerment depends on the strength of the organizational culture. Bolat, Bolat, and Yüksel (2016) stated that a hierarchy culture has a positive effect on psychological empowerment. Emet (2006), on the other hand, revealed that the effect of organizational culture on psychological empowerment remains limited. In this study, the research findings reveal that the culture of task-oriented and the culture of success-oriented positively affect psychological empowerment. In this case, it is possible to say that directing the organizations according to the support and goals of psychologically strengthens teachers.

Another result of the research is that my psychological climate positively affects psychological empowerment. In this case, when teachers' personal perceptions about their schools are positive, their job competencies and effects are also positively affected. This result is important since there is no other study in the literature that examines the relationship between psychological climate and psychological empowerment.

The variables of power sources, psychological empowerment, school culture, and psychological climate were generally often tried to be associated in binary and it was observed that the variables affect each other. However, it is an important result that there is no other study evaluating the four variables together and that the school culture variable is the most dominant and effective variable in the psychological empowerment of teachers.

\section{REFERENCES}

Akdemir, A. (2017). Otel işletmelerinde örgüt iklimine etki eden yönetsel güç kaynaklarının belirlenmesi (Yayınlanmamış yüksek lisans tezi) [The Determination of Managerial Power Source Affecting Organizational Climate in Hotel Enterprises]. Nevşehir Hacı Bektaş Veli University, Nevşehir. http://acikerisim.nevsehir.edu.tr/bitstream/handle/20.500.11787/305/Ahmet_Akdemir_Tez.pdf?sequ ence $=1$ \&isAllowed $=y$

Akgül, R. (2013). Ortaöğretim kurumlarındaki yöneticilerin yönetimde gücü kullanma stillerinin öğretmen algılarına göre örgütsel bağlıı̆̆a etkisi (Yayımlanmamış yüksek lisans tezi) [Effect of secondary scholl administrators' power use styles in management on organizational commitment according to teachers' perceptions]. Trakya University, Edirne.

https://tez.yok.gov.tr/UlusalTezMerkezi/tezSorguSonucYeni.jsp

Altınkurt, Y., Yılmaz, K., Erol, E., \& Salalı, E. T. (2014). Okul müdürlerinin kullandığı güç kaynakları ile öğretmenlerin örgütsel sinizm algıları arasındaki ilişki [Relationship between School Principals' Use of Power Sources and Teachers' Organizational Cynicism Perceptions]. Journal of Teacher Education and Educators, 3(1), 25-52. http://jtee.org/document/issue5/MAK2.pdf

Altunkese, T. N. (2002). Psikolojik iklimin örgüte adama ve örgütsel vatandaşlık davranışı ile ilişkisi üzerine bir araştırma (Yayımlanmamış yüksek lisans tezi) [A Study of relationship between psychological climate, organizational commitment and organizational citizenship behavior in a public organization]. Osmangazi University, Eskişehir. https://tez.yok.gov.tr/UlusalTezMerkezi/tezSorguSonucYeni.jsp

Amenumey, E. K., \& Lockwood, A. (2008). Psychological climate and psychological empowerment: An exploration in a luxury UK Hotel Group. Tourism and Hospitality Research, 8(4), 265-282.

Argon, T. \& Limon, İ. (2017). Psikolojik iklim ölçeğinin Türkçe'ye uyarlanması: Geçerlik ve güvenirlik çalışması [The adaptation of psychological climate scale into Turkish: the study of validity and reliability]. International Journal of Human Sciences, 14(3), 2888-2901. https://www.j-

humansciences.com/ojs/index.php/IJHS/article/view/4614/2300 
Arpaguş, A. U. (2011). Okul kültürünün öğretmen davranışlarına etkisi (Yüksek lisans tezi) [The effect of school culture on behaviors of teachers]. Trakya University, Edirne. https://tez.yok.gov.tr/UlusalTezMerkezi/tezSorguSonucYeni.jsp

Ashforth, B.E. (1989) The experience of powerlessness in organizations. Organizational Behavior and Human Decision Processes, 43, 207-42.

Aslanargun, E. (2009). Illköğretim ve lise müdürlerinin okul yönetiminde kullandığı güç türleri (Yayımlanmamış Doktora Tezi) [The power sources that principals handle in Turkish public elementary and secondary school administration]. Ankara University, Ankara. https://tez.yok.gov.tr/UlusalTezMerkezi/tezSorguSonucYeni.jsp

Ateş, F. (2017). Ö. Turunç \& H. Turgut (Ed.), Yönetim ve strateji: 101 teori ve yaklaşım içinde [ Management and strategy: 101 in theory and approach]. (125-159). Ankara: Siyasal Publishing.

Atmaca, T. (2014). Okul yöneticilerinin kullandıkları güç türleri ile öğretmenlerin yaşadıkları yıldırma, örgütsel bağlılık ve örgütsel sinizm arasındaki ilişki (Yayımlanmamış yüksek lisans tezi). [Relationship among the power types of school principals' and teachers' mobbing, organizational commitment and organizational cynicism perception]. Gazi University, Ankara. https://tez.yok.gov.tr/UlusalTezMerkezi/tezSorguSonucYeni.jsp

Avolio, B. J., Zhu, W., Koh, W., \& Bhatia, P. (2004). Transformational leadership and organizational commitment: Mediating role of psychological empowerment and moderating role of structural distance. Journal of organizational behavior, 25(8), 951-968, http://dx.doi. org/10.1002/job.283

Aydın, M. (2010). Eğitim yönetimi [Education Management ]. (9th Edition). Ankara: Hatiboğlu Publishing

Ayık, A. \& Şayir, G. (2014). Okul müdürlerin öğretimsel liderlik davranışları ile örgüt iklimi arasındaki ilişki [The relation between, instructional leadership behaviours of school principals and organizational climate]. Electronic Journal of Social Sciences, 13(49), 253-279. https://www.researchgate.net/publication/275228410_OKUL_MUDURLERIN_OGRETIMSEL_LIDERLIK_ DAVRANISLARI_ILE_ORGUT_IKLIMI_ARASINDAKI_ILISKI

Balcı, A. (1993). Etkili okul: Kuram, uygulama ve araştırma [Effective school: Theory, practice and research]. Ankara: Erek Publishing.

Barkhi, R. \& Kao, Y. C. (2011). Psychological climate and decision-making performance in a GDSS context. Information and Management, 48, 125-134.

Barret, P. (2007). Structural equation modelling: Adjudging model fit. Personality and Individual Differences $42,815-824$.

Bell, N.E. \& Staw, B.M. (1980) People as Sculptors versus Sculptures: The roles of personality and personal control in organizations. In Arthur, M.B., Hall, D.T. and Lawrence, B.S. (Eds.) Handbook of career theory (pp. 232-51). New York: Cambridge University Press.

Bentler, P. M., \& Bonett, D. G. (1980). Significance tests and goodness of fit in the analysis of covariance structures. Psychological Bulletin, 88(3), 588-606.

Biswas, S. (2010). Relationship between psychological climate and turnover intentions and its impact on organisational effectiveness: A study in Indian organisations. Indian Institute of Management Bangalore Management Review, 22, 102- 110.

Biswas, S., \& Varma, A. (2007). Psychological climate and individual performance in India: test of mediated model. Employee Relations, 29 (6), 664-676.

Blau, P. (1964). Exchange and power in social life. New York: Wiley.

Bogler, R., \& Somech, A. (2004). Influence of teacher enpowerment on teachers' organizational commitment, professional commitment and organizational citizenship behavior in schools. Teaching and Teacher Education, 538-625.

Bolat, T., Bolat, O. İ., \& Yüksel, M. (2016). Hizmetkâr liderlik ve psikolojik güçlendirme ilişkisi: Örgüt kültürünün düzenleyici etkisi [The Relationship Between Servant Leadership and Psychological Empowerment: Moderating Effect of Organizational Culture]. Balıkesir University The Journal of Social Sciences Institute, 19(36), 1. http://dspace.balikesir.edu.tr/xmlui/bitstream/handle/20.500.12462/3851/tamerbolat.pdf? sequence $=1$ \&isAllowed $=y$

Boudrias, J. S., Morin, A. J., \& Lajoie, D. (2014). Direc- tionality of the associations between psychological em- powerment and behavioural involvement: A longitudinal autoregressive cross-lagged analysis. Journal of Occupational and Organizational Psychology, 87(3), 437-463, http://dx.doi.org/10.1111/joop.12056 
Brown, S. P., \& Leigh, T. W. (1996). A new look at psychological climate and its relationship to job involvement, effort, and performance. Journal of Applied Psychology, 81(4), 358-368.

Byrne, B. M., Shavelson, R. J., \& Muthen, B. (1989). Testing for the equivalence of factor covariance and mean structures: The issue of partial measurement in variance. Psychological Bulletin, 105, 456-466.

Can, H., Aşan, Ö., \&Aydın, E. M. (2006). Örgütsel davranış [Organizational behavior]. İstanbul: Arıkan Publishing.

Chen, C.-C. (2011). Factors affecting high school teachers' knowledge-sharing behaviors. Social Behavior and Personality: An international journal, 39, 993-1008.

Cooke, R., \& Szumal, J.L (1993). Measuring normative beliefs and shared behavioral expectations in organizations. Psychological Reports. 72, 1299-1330.

Cömert, M. (2014). Öğretmenlerin örgütsel bağllık düzeyleri ile okul müdürlerinin kullandıkları örgütsel güç kaynakları arasındaki ilişkinin incelenmesi (Yayımlanmamış yüksek lisans tezi) [Analysis of relation between teacher's organizational commitment level and principals's power sources]. Sütçü İmam University, Kahramanmaraş. https://tez.yok.gov.tr/UlusalTezMerkezi/tezSorguSonucYeni.jsp

Cresweel, J. W. (2017). Nicel ve nitel Araştırmanın planlanması, yürütülmesi ve değerlendirilmesi [Planning, conducting and evaluating quantitative and qualitative research]. (H. Ekşi, Tra. Ed.). İstanbul: Edam.

Cropanzano, R. ve Mitchell, M. (2005). Social exhange theory: An Interdiciplinary review. Journal of Management, 31(6), 874-900.

Çalışkur, A. (2015). Örgütlerde Güç Olgusu ve Gücün Kullanımı [Power Fact and Using Power in Organizations]. Cankiri Karatekin University Journal of Institute of Social Sciences, 7(1): 029-048. http://sbedergi.karatekin.edu.tr/Makaleler/651995685_2-

\%c3\%96rg\%c3\%bctlerde\%20G\%c3\%bc\%c3\%a7\%20Olgusu\%20ve\%20G\%c3\%bcc\%c3\%bcn\%20Kulla n\%c4\%b1m\%c4\%b1.pdf

Çavuş, M. F. ve Akgemci, T. (2008). İşletmelerde personel güçlendirmenin örgütsel yaratıcılık ve yenilikçiliğe etkisi: İmalat sanayiinde bir araştırma [The effect of empowering staff on organizational creativity and innovation: a research in the manufacturing industry]. Selçuk University Journal of Social Sciences Institute, 20, 229-244. http://dergisosyalbil.selcuk.edu.tr/susbed/article/view/365

Çekmecioğlu, H. \& Eren, E. (2007). Psikolojik güçlendirme, örgütsel bağlılık ve yaratıcı davranış arasındaki ilişkilerin değerlendirilmesi [Assessment of Relationship Between Psychological Empowerment, Organizational Commitment and Creative Behavior]. Journal of Administration, 18(57), 1325. http://kutuphane.dogus.edu.tr/mvt/pdf.php?lng=0\&recid=6251\&pdf=0006241\&journalnu

Çöl, G. (2008). Algılanan güçlendirmenin işgören performansı üzerine etkileri [At the effects of perceived empowerment on employee performance]. Journal of Doğuş University, 9(1), 35-46. https://openaccess.dogus.edu.tr/xmlui/handle/11376/391?show=full\#sthash.IQtfHoxq.dpbs

Day, D. V., \& Bedeian, A. G. (1991). Predicting job performance across organizations: The interaction of work orientation and psychological climate. Journal of Management, 17(3), 589-600.

Deci, E.L., Connell, J.P. \& Ryan, R.M. (1989) Self-determination in a work organization. Journal of Applied Psychology, 74, 580-90.

Demir, K. (2010). Insan kaynakları uygulamalarının işyerinde psikolojik güçlendirmeye etkisi: Bir araştırma (Yayımlanmamış yüksek lisans tezi) [The effect of human resources practices on psychological empowerment in workplace: A research]. Yıldız Teknik University, İstanbul. https://tez.yok.gov.tr/UlusalTezMerkezi/tezSorguSonucYeni.jsp

Doğan, S. (2006). Personel Güçlendirme Rekabette Başarının Anahtarı [Empowerment is the Key to Success in Competition]. İstanbul: Kare Publishing.

Emet, C. (2006). Personelin Güçlendirilme Algıları ile Örgütsel Kültür Arasındaki Illişkinin Bankacılık Sektöründe Ampirik Olarak Incelenmesi. (Yüksek Lisans Tezi) [An empirical evaluation of the relation between employee's perception of empowerment and the corporate culture in the banking sector]. Dumlupınar University, Kütahya. https://tez.yok.gov.tr/UlusalTezMerkezi/tezSorguSonucYeni.jsp

Erkutlu, H. \& Chafra, J. (2013). Effects of trust and psychological contract violation on authentic leadership and organizational deviance. Management Research Review, 36(9), 828-848, http://dx.doi.org/10.1108/MRR-06-2012-0136

Fraenkel, J. R. \& Wallen, N. E. (2006). How to design and evaluate research in education (6th ed.). Boston: McGraw-Hill.

French, J. R. P., \& Raven, B. (1959). The bases of social power. In D. Cartwright \& A. Zander (Eds.), Studies in social power (pp. 150-67). Ann Arbor, MI: University of Michigan.

Ghanbari, S. and Eskandari, A. (2014). Organizational Climate, Job Motivation and OCB. International Journal of Management Perspective, 1(3), 1-14. 
Ghani, N.A.A. ve Hussin, T.A.B. (2009). The Impact of Psychological Empowerment on Lecturers' Innovative Behaviour in Malaysian Private Higher Education Institutions. Canadian Social Science, 5(4):54-62.

Gligorović, M., \& Buha., N. (2016). Influence of Inhibitory Control on Planning Abilities in Children With Mild Intellectual Dısability. Fakultet za specijalnu edukaciju i rehabilitaciju, 187-195.

Gül, H. \& Çöl, G. (2004). Personeli Güçlü Kılan Örgütsel Yapı Oluşturmada SosyalYapısal Öncülerin Güçlendirmeye Olan Etkileri ve Sonuçları Üzerine Bir Araştırma [Research on the Effects and Results of Social Structural Pioneers on Empowerment in Creating Organizational Structures that Empower Personnel]. Journal of Atatürk University, 18(3-4), 249-272. https://dergipark.org.tr/en/pub/atauniiibd/issue/2684/35237

Hallinger, P., Bickman, L., \& Davis, K. (1996). School context, principal leadership, and student reading achievement. The Elementary School Journal, 96, 527-549.

Handy, C.B. (1981). Understanding organization (second edition). Aylesbury: Hazell Watson Ltd.

Harrison, R. (1972). Understanding your organization's character. Harvard Business Review, 119-128

Heck, R. H. \& Marcoulides, G. A. (1996) School culture and performance: testing the invariance of an organizational model. School Effectiveness and School Improvement, 7(1), 76-96.

Hoy, W. K. (1990) Organizational climate and culture: a conceptual analysis of the school workplace. Journal of Educational and Psychological Consultation, 1(2), 149-168.

$\mathrm{Hu}$, L., \& Bentler, P. M. (1999). Cutoff criteria for fit indexes in covariance structure analysis: Conventional criteria versus new alternatives. Structural Equation Modeling, 6(1), 1-55.

Ihtiyaroğlu, N. (2017). Yapısal ve psikolojik güçlendirmenin öğretmen motivasyonu üzerindeki etkisi [The Effect of Structural and Psychological Empowerment on Teachers' Motivation]. Journal of Kırıkkale University of Education Faculty, (2), 361-378.

https://www.researchgate.net/publication/325248662_Ihtiyaroglu_N_2017_Yapisal_ve_psikolojik_guc lendirmenin_ogretmen_motivasyonu_uzerindeki_etkisi_Kirikkale_Universitesi_Sosyal_Bilimleri_Dergisi _72_361-378

Jahangir, N., Akbar, M. \& Begum, N., (2006). The role of social power, procedural justice, organizational commitment and job satisfaction to engerder organizational citizenship behavior. ABAC Journal, 26(3), 21-36.

James, L. A., \& James, L. R. (1989). Integrating work environment perceptions: Explorations into the measurement of meaning. Journal of Applied Psychology, 74, 739-751.

James, L. R., \& Jones, A. P. (1974). Organizational climate: A review of theory and research. Psychological Bulletin, 81(12), 1096-1112. https://doi.org/10.1037/h0037511

James, L. R., \& Sells, S. B. (1981). Psychological Climate: Theoretical Perspectives and Empirical Research. D. Magnusson içinde, Toward A Psychology of Situations: An Interactional Perspective. New Jersey: Lawrence Erlbaum Associates.

James, L. R., Hartman, A., Stebbins, M. W., \& Jones, A. P. (1977). Relationship between psychological of climate and a vie model for work motivation. Personnel Psychology, 30, 229-254.

Joyce, W. \& Slocum, J. (1982). Climate Discrep-ancy: Refining the Concepts of Psychological and Organizational Climate. Human Relations, 35 (11). 951-72.

Jöreskog, K. G. (2004). On chi-squares for the independence model and fit measures in Lisrel. http://www.ssicentral.com/lisrel/techdocs/ftb.pdf adresinden

Kadıoğlu Ateş, H., \& Vatansever Bayraktar, H. (2018). Sınıf öğretmenlerinin okul kültürü algısı ile iş doyumu arasındaki ilişki [The Effect of School Culture on Teachers' Job Satisfaction]. Electronic Turkish Studies, 13(19), 127- 162 http://static.dergipark.org.tr/articledownload/1a74/74e8/0e7b/5e3433da4a23c.pdf?

Kahn, W. A. (1990). Psychological conditions of personal engagement and disengagement at work. Academy of Management Journal, 33, 692-724.

Kanbur, E. (2018). Havacılık sektöründe psikolojik güçlendirme, iş performansı ve işten ayrılma niyeti arasındaki ilişkilerin incelenmesi [Investigation of relationships between psychological empowerment, job performance and intention to leave in a aviation sectoe]. Int. Journal of Management Economics and Business, 14(1), 147-162. http://ijmeb.org/index.php/zkesbe/article/view/1451

Karagonlar, G., Öztürk, E. B. \& Özmen, Ö. N. (2015). Çalışanın örgütle sosyal mübadele algısı ve işten ayrılma niyeti: İşe cezbolmanın ve öz yeterliliğin rolü [Employee's perception of social exchange with the organization and intention to quit: The role of attractiveness and self-efficacy]. METU Studies in Development 42(3), 411. https://www.researchgate.net/publication/303703601_Calisanin_orgutle_sosyal_mubadele_algisi_ve_i sten_ayrilma_niyeti_Ise_cezbolmanin_ve_oz_yeterliligin_rolu 
Kettinger, W. J., Li, Y., Davis, J. M., \& Kettinger, L. (2015). The roles of psychological climate, information management capabilities, and IT support on knowledge-sharing: an MOA perspective. European Journal of Information Systems, 24, 59-75.

Kilian, C. (1999). The two sides of the school culture coin. Technos Quarterly, 8/3. http://www.technos.net/journal/volume8/3kilian.htm

Kirkman, B. L., \& Rosen, B. (1999). Beyond Self-man- agement: Antecedents and Consequences of Team Empowerment. Academy of Management Journal, 42, 58-74, http://dx.doi.org/10.2307/256874

Kline, R. B. (2011). Principles and practice of structural equation modeling. New York: The Guilford Press.

Koşar, S. (2008). Illköğretim okulu yöneticilerinin yönetimde gücü kullanma stilleri ile örgüt kültürü arasındaki ilişki (Yayımlanmamış yüksek lisans tezi) [The relationship between primary school supervisors? styles of using power in management and organizational culture]. Gazi University, Ankara. https://tez.yok.gov.tr/UlusalTezMerkezi/tezSorguSonucYeni.jsp

Koys, D. J., \& DeCotiis, T. A. (1991). Inductive measures of psychological climate. Human Relations, 44(3), 265- 285.

Lee, K. L., \& Low, G. T. (2009). The exercise of social power and the effect of ethnicity: Evidence from Malaysian's industrial companies. International Business Research, 1(2), 53-65. doi:10.5539/ibr.v1n2p53

Liden, R. C., Wayne, S. J., \& Sparrowe, R. T. (2000). An examination of the mediating role of psychological empowerment on the relations between the job, inter- personal relationships and work outcomes. Journal of Applied Psychology, 85, 407-416, http://dx.doi. org/10.1037/0021-9010.85.3.407

Lunenburg, F. C. and Ornstein, A. C. (2004) Educational administration: Concepts and practices. Belmont, CA Wadsworth/Thomson Learning.

Mac Neil, J., Prater, D. L., \& Bush, S. (2009). The effects of school culture and climate on student achievement. International Journal of Leadership in Education, 12(1), 73-84, DOI: $10.1080 / 13603120701576241$

Manning, R. L. (2010). Development of the psychological climate scale for small business. Journal of New Business Ideas \& Trends, 8(1), 50-65.

Martin, A. J., Jones, E. S., \& Callan, V. J. (2005). The role of psychological climate in facilitating employee adjustment during organizational change. European Journal of Work and Organizational Psychology 14(3), 263-289.

Martin, C. A., \& Bush, A. J. (2006). Psychological cli- mate, empowerment, leadership style, and custom- eroriented selling: An analysis of the sales man- ager-salesperson dyad. Journal of the Academy of Marketing Science, 34, 419-438, http://dx.doi. org/10.1177/0092070306286205

Maydeu-Olivares, A. \& Garcia Forero, C. (2010). Goodness-of-fit testing. International Encyclopedia of Education, 7, 190-196.

McDougall, M. \& Beattie, R. S. (1998) The missing link? Understanding the relationship between individual and organisational learning. International Journal of Training and Development, 2, 288- 299.

O'Neill, B., \& Arendt, L. A. (2008). Psychological climate and work attitudes: The Importance of telling the right story. Journal of Leadership and Organizational Studies, 14(4), 353-370.

Özcan, K., Karataş, İ. H., Çağlar, Ç. \& Polat, M. (2014). Eğitim fakültesi yöneticilerinin güç kullanma biçimlerinin örgüt kültürüne etkisi: Bir durum çalışması [The effect of power use styles of education faculty administrators on organizational culture: A case study]. Educational Administration: Theory and Practice, 14(2), 545-569.

https://www.academia.edu/42453189/Eğitim_Fakültesi_Yöneticilerinin_Güç_Kullanma_Biçimlerinin_Ö rgüt_Kültürüne_Etkisi_Bir_Durum_Çalışması

Özdemir, S. (2012). İlköğretim okullarında okul kültürü ile örgütsel sağlık arasındaki ilişki [The Relationship between School Culture and Organizational Health in Primary Schools]. Educational Administration: Theory and Practice, 4(4), 599-620.

Özgenel, M. (2018). Modeling the relationships between school administrators' creative and critical thinking dispositions with decision making styles and problem solving skills. Educational Sciences: Theory \& Practice, 18, 673-700. http:// dx.doi.org/10.12738/estp.2018.3.0068

Pheysey D.C. (1993). Organizational cultures: Types and transformations. London: Routledge.

Polatcı S., \& Özçalık. F. (2013). Yapısal ve psikolojik güçlendirmenin işyeri nezaketsizliği ve tüken- mişliğe etkisi [The effects of structural and psychologicial empowerment on workplace incivility and burnout]. Sakarya University Journal of Business Science, 1(1), 17-34. http://www.acarindex.com/dosyalar/makale/acarindex-1423904898.pdf

Powers, J. M. (2009). Charter schools: From reform imagery to reform reality. New York, Palgrave Macmillan. Retrieved from https://doi.org/10.1057/9780230622111_1 
Rahim, M. A. \& Afza, M. (1993). Leader power, commitment, satisfaction, compliance and propensity to leave a job among US accountants. The Journal of Social Psychology, 133(5), 611-625.

Rhoades, L., Eisenberger, R. \& Armeli, S. (2001). Affective commitment to the organization: The contribution of perceived organizational support. Journal of Applied Psychology 86(5), 825-836.

Rice, T. W. \& Steele, B. J. (2004). Subjective well-being and culture across time and space. Journal of CrossCultural Psychology, 35, 633- 647.

Russell, B. (1938). Power, a new social analysis. New York: W. W. Norton.

Saphier, J., \& King, M. (1985). Good seeds grow in strong cultures. Educational Leadership, 42(6), 67-74.

Schein, E. H. (1985) Organizational Culture and Leadership (San Francisco, CA: Jossey-Bass).

Schein, E. H. (1996) Culture: the missing concept in organization studies. Administrative Science Quarterly, 41, 229-240.

Schermelleh-Engel, K., Moosbrugger, H., \& Müller, H. (2003). Evaluating the fit of structural equation models: tests of significance and descriptive goodness-of-fit measures. Methods of Psychological Research Online, 8(2), 23-74.

Schneider, B. \& Reichers, A. E. (1983). On the etiology of climates. Personnel Psychology, 36, 19-39

Schoen, L. T. \& Teddlie, C. (2008). A new model of school culture: A response to a call for conceptual clarity. School Effectiveness and School Improvement, 19(2), 129-153. Retrieved from https://doi.org/10.1080/09243450802095278

Schumacker, R. E., \& Lomax, R. G. (2010). A beginner's guide to structural equation modeling. New York: Routledge Taylor ve Francis Group.

Schyns, B., Veldhoven, M. v., \& Wood, S. (2009). Organizational climate, relative psychological climate and job satisfaction: The example of supportive leadership climate. Leadership \& Organization Development Journal, 30(7), 649-663.

Sezgin, F. (2010). Psikolojik dayanıklılığı düşük ve yüksek öğretmenlerde örgütsel bağlıık üzerine bir araştırma [Investigating the pyschologicial hardıness levels of primary school teachers]. 19th National Educational Sciences Congress Abstracts (92-93). Lefkoşa: International Kıbrıs University Education Faculty. https://www.yumpu.com/tr/document/read/44713979/ilkogretim-okuluogretmenlerinin-psikolojik-dayankllk-duzeylerinin-

Spreitzer, G. M. (1995). Psychological empowerment in the workplace: Dimensions, measurement, and validation. Academy of Management Journal, 38(5), 1442-1465, http://dx.doi.org/10.2307/256865

Strutton, D., Pelton, L. E., \& Lumpkin, J. R. (1993). The influence of psychological climate on conflict resolution strategies in franchise relationships. Journal of the Academy of Marketing Science, 21(3), 207-215.

Sürgevil, O., Tolay, E., \& Topoyan, M. (2013). Yapısal güçlendirme ve psikolojik güçlendirme ölçeklerinin geçerlilik ve güvenilirlik analizleri [The Validty and Reliability Analysis of Structural Empowerment and Psychological empowerment Scales]. Journal of Yasar University, 8(31), 5371-5391. https://www.researchgate.net/publication/296431464_Yapisal_Guclendirme_ve_Psikolojik_Guclendir me_Olceklerinin_Gecerlilik_ve_Guvenilirlik_Analizleri_-

_The_Validty_and_Reliability_Analysis_of_Structural_Empowerment_and_Psychological_empowermen t_Scales

Şentürk, C. \& Sağnak, M. (2012). Illköğretim okulu müdürlerinin liderlik davranışları ile okul iklimi arasındaki ilişki [The relationship between leadership behavior of primary school managers and school climate]. Journal of Educational Sciences, 10(1), 29-47.

https://dergipark.org.tr/tr/pub/tebd/issue/26138/275287

Şimşek, Ö. F. (2007). Introduction to Structural Equation Modeling, Basic Principles and LISREL Applications. Ankara: Ekinoks.

Tajasom, A. \& Ahmad, A. Z. (2011). Principals' leadership style and school climate: Teachers' perspectives from Malaysia. The International Journal of Leadership in Public Services, 7(4), 314-333.

Terzi, A. R. (2005). Illköğretim okullarında örgüt kültürü [Organizational Culture ın Primary Schools]. Educational Sciences: Theory \& Practice, 43(43), 423-442.

https://dergipark.org.tr/tr/pub/kuey/issue/10354/126787

Thayer, S. F. (2008). Psychological climate and its relationship to employee engagement and organizational citizenship behaviour (Unpublished doctoral dissertion) Capella University, Minneapolis.

Thomas, K. W., \& Velthouse, B. A. (1990). Cognitive elements of empowerment: An "interpretive" model of intrinsic task motivation. Academy of Management Review, 15(4), 666-681, http://dx.doi.org/10.5465/ AMR.1990.4310926 
Tolay, E., Sürgevil, O. \& Topoyan, M. (2012). Akademik çalışma ortamında yapısal ve psikolojik güçlendirmenin duygusal bağlıık ve iş doyumu üzerindeki etkileri [Impact of Structural and Psychological Empowerment on Affective Commitment and Job Satisfaction in Academic Work Setting]. Ege Academic Review, 12(4), 449- 465.

https://www.researchgate.net/publication/307798146_Akademik_Calisma_Ortaminda_Yapisal_ve_Psi kolojik_Guclendirmenin_Duygusal_Baglilik_ve_Is_Doyumu_Uzerindeki_Etkileri

Toytok, E. \& Uçar, L. (2018). Okul yöneticilerinin kullandıkları güç türleri ve örgütsel depresyon: Bir ilişkisel tarama modeli [The Power Types that are Used by School Administrators and the Organizational Depression: A Corrrelational Screening Model]. Ekev Journal 22(76). http://www.ekevakademi.org/Makaleler/1743889194_06\%20Esef\%20Hakan\%20TOYTOKLeyla\%20UCAR.pdf

Wang, Y. (2015). Examining organizational citizenship behavior of Japanese employees: A multidimensional analysis of the relationship to organizational commit- ment. International Journal of Human Resource Management, 26(4), 425-444, http://dx.doi.org/10.1080/09 585192.2011.560882

Wei, Yu-Chen, Han, Tzu-Shian \& Hsu, I-Chieh(2010). High-performance HR practices and OCB: Aacrosslevel investigation of a causal path', The International Journal of Human Resource Management, 21(10), 1631-1648, Doi; 10.1080/09585192.2010. 500487

Yıldız, B. \& Yıldız, H. (2015). The effect of servant leadership on psychological ownership: The moderator role of perceived organizational support. Journal of Global Strategic Management 9(2), 65-77.

Yılmaz, F. (2009). Eğitim örgütlerinde örgüt kültürünün öğretmenlerin iş motivasyonu üzerindeki etkisi (Yayımlanmamı yüksek lisans tezi). [Effects of organizational culture in educational organizations on teachers' job motivation]. Selçuk University, Konya.

https://tez.yok.gov.tr/UlusalTezMerkezi/tezSorguSonucYeni.jsp

Yılmaz, K., \& Altınkurt, Y. (2012). Okul yöneticilerinin kullandıkları güç kaynakları ile öğretmenlerin iş doyumu arasındaki ilişki [Relationship between school administrators' power sources and teachers' job satisfaction]. Journal of Kastamonu Education Faculty, 20(2), 385-402. https://dergipark.org.tr/tr/pub/kefdergi/issue/48697/619533

Zhang, A. Y., Song, L. J., Tsui, A. S., \& Fu, P. P. 2014. Employee responses to employment- relationship practices: The role of psychological empowerment and traditionality. Journal of Organizational Behavior, 35(6), 809-830.

Zohar, D. \& Luria, G. (2004). Climate as a social-cognitive construction of supervisory safety practices: Scripts as Proxy of behaviour patterns. Journal of Applied Psychology, 89(2), 322-333. 


\section{Güç Türleri, Psikolojik Güçlendirme, Okul Kültürüi ve Psikolojik Iklim Arasındaki Ilişkiler: Bir Yapısal Eşitlik Modellemesi}

\author{
Dr.öğr.Üyesi Pınar Mert \\ Istanbul Sabahattin Üniversitesi-Türkiye \\ pinar.mert@izu.edu.tr
}

\author{
Dr.Öğr.Üyesi Mustafa Özgenel \\ Istanbul Sabahattin Üniversitesi-Türkiye \\ mustafa.ozgenel@izu.edu.tr
}

\begin{abstract}
Özet:
Bu araştırma, psikolojik güçlendirmeyi etkilediği düşünülen okul yöneticilerinin güç kaynakları, okul kültürü ve psikolojik iklimi hakkında bir çıkarım yapmak amacıyla hazırlanmıştır. Çalışma, önerilen kavramsal modeli test etmek için korelasyon araştırma modeline göre tasarlanmış, yürütülmüş ve bu model Yapısal Eşitlik Modeli (SEM) ile test edilmiştir. Araştırmaya 358 ögretmen (252 kadın ve 97 erkek) katılmıştır. Bulgular uyum indekslerine göre değerlendirilmiş ve yapılan modifikasyon sonucunda modelin uyum değerlerinin mükemmel düzeyde olduğu tespit edilmiştir $\left(\chi^{2}=5.766 ; d f=7 ; p=.567 ; \chi^{2} / d f=.824 ; \quad S R M R=.021 ; \quad G F I=.995 ;\right.$ $A G F I=981 ; N F I=.994 ; T L I=1.000 ; C F I=1.000 ; R M S E A=.000)$. Elde edilen modele göre; okul müdürlerinin kullandıkları yumuşak güç türleri, psikolojik güçlendirmeyi olumlu etkilerken; sert güç türleri psikolojik güçlendirmeyi etkilememektedir. Yumuşak güç türleri, görev kültürünü, başarı kültürünü ve destek kültürünü olumlu etkilerken; bürokratik kültürü olumsuz etkilemektedir. Sert güç türleri, okulun kültürel boyutlarını etkilememektedir. Yumuşak güç türleri, psikolojik iklimi olumlu etkilerken; sert güç türlerinin etkisi bulunmamaktadır. Başarı kültürü ve görev kültürü, psikolojik güçlendirmeyi olumlu etkilerken; bürokratik kültür ve başarı kültürü, psikolojik güçlendirmeyi etkilememektedir. Başarı kültürü, görev kültürü ve destek kültürü, psikolojik iklimi olumlu etkilerken; bürokratik kültür etkilememektedir. Psikolojik iklim, psikolojik güçlendirmeyi olumlu etkilemektedir. Araştırma sonucunda okul kültürünün psikolojik iklim ve psikolojik güçlendirmeyi etkileyen önemli bir faktör olduğu görülmüştür.
\end{abstract}

Anahtar Kelimeler: Psikolojik güçlendirme, Okul Kültürü, Psikolojik Iklim, Güç Kaynakları

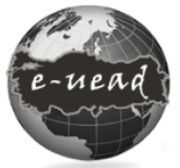

E-Uluslararası Eğitim Araştırmaları Dergisi, Cilt: 11, Sayı: 2, 2020, ss.68-91

DOI: 10.19160/ijer.751727

Gönderim : 2020-06-11 Kabul : 2020-07-06

\section{Önerilen Atıf:}

Pınar, M., Ozgenel, M. (2020). Güç Türleri, Psikolojik Güçlendirme, Okul Kültürü ve Psikolojik Iklim Arasındaki Ilişkiler: Bir Yapısal Eşitlik Modellemesi , E-Uluslararası Eğitim Araştırmaları Dergisi, Cilt: 11, Sayı: 2, 2020, ss. 68-91, DOI: 10.19160/ijer.751727

\section{GENIŞLETILMIŞ ÖZET}


Problem: Araştırmalar, psikolojik güçlendirme sayesinde çalışanların örgütlerine daha fazla bağlı oldukların (Avolio, Zhu, Koh ve Bhatia, 2004; Liden, Wayne ve Sparrowe, 2000) ve daha üretken olduklarını (Martin ve Bush, 2006; Çavuş ve Akgemci, 2008) ortaya koymuşlardır. Ancak alanyazında psikolojik güçlendirmeyi etkileyen öncül değişkenleri belirlemeye yönelik çalışmaların fazla yapılmadığı görülmektedir. Bu çalışmada, psikolojik güçlendirmeyi etkilediği düşünülen okul yöneticilerinin güç kaynaklarl, okul kültürü ve psikolojik iklimi üzerinde durulmuş ve Şekil 1'de verilen teorik bir model önerilmiştir.

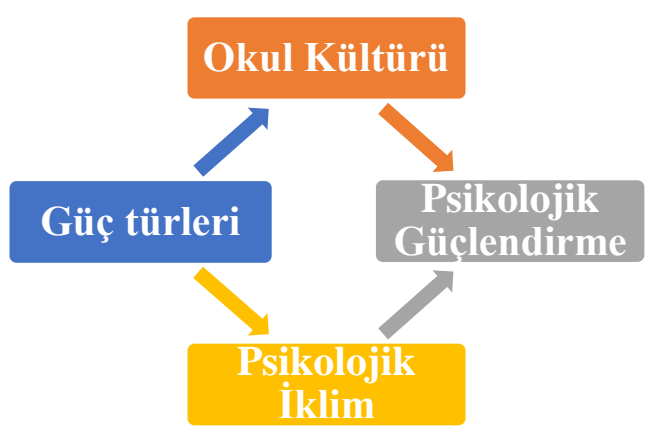

Şekil 1. Kavramsal model
Şekil 1'de verilen kavramsal modele göre;

$\checkmark$ Güç türleri, okul kültürünü, psikolojik iklimi ve psikolojik güçlendirmeyi etkilemektedir.

$\checkmark$ Okul kültürü, psikolojik güçlendirmeyi etkilemektedir.

$\checkmark$ Okul kültürü, psikolojik iklimi etkilemektedir.

$\checkmark$ Psikolojik iklim, psikolojik güçlendirmeyi etkilemektedir.

$\checkmark$ Güç türleri ile okul kültürü birlikte, psikolojik iklimi,

$\checkmark$ Güç türleri ile okul kültürü birlikte, psikolojik güçlendirmeyi,

$\checkmark$ Güç türleri ile psikolojik iklim birlikte, psikolojik güçlendirmeyi,

$\checkmark$ Okul kültürü ile psikolojik iklim birlikte, psikolojik güçlendirmeyi,

$\checkmark$ Güç türleri ile okul kültürü ve psikolojik iklimi birlikte, psikolojik güçlendirmeyi etkilemektedir.

\section{Yöntem:}

Bu çalışmada bağımlı ve bağımsız değişkenler arasındaki ilişkileri açıklamak için korelasyon araştırma desenine göre tasarlanmış ve yürütülmüş̧ür. Kavramsal model ile toplanan veriler, Yapısal Eşitlik Modeli'nde (SEM-SEM) test edilmiștir. Çalışmaya katılan 349 öğretmenin \%72.2'si (252) kadın, \%27.8'i (97) erkektir. Araştırmada veriler, Brown ve Leigh (1996) tarafindan geliştirilen, Argon ve Limon (2017) tarafından Türkçeye uyarlanan Psikolojik iklim Ölçeği (PiÖ), Terzi (2005) tarafından geliştirilen Okul Kültürü Ölçeği (OKÖ), Aslanargun (2009) tarafindan geliştirilen Güç Türleri Ölçeği (GTÖ) ile Spreitzer (1995) tarafından geliştirilen ve Sürgevil, Tolay ve Topoyan (2013) tarafından Türkçeye uyarlanan Psikolojik Güçlendirme Ölçeği (PGÇ) aracılığıyla toplanmıştır.

Bulgular: Önerilen kavramsal model, toplanan verilerle test edilmiştir. Modeli değerlendirmek için regresyon yol katsayıları ve uyum indeksleri incelenmiştir. Anlamlı olmayan regresyon yol katsayıları modelden silinmiş, yeniden analiz yapılmış ve ölçüm modelinin mükemmel uyum gösterdiği tespit edilmiştir $\left(\chi^{2}=5.766 ; d f=7 ; p=.567 ; \chi^{2} / d f=.824 ; S R M R=.021 ; G F I=.995 ; A G F I=981\right.$; $N F I=.994 ; T L I=1.000 ; C F I=1.000 ; R M S E A=.000)$. 


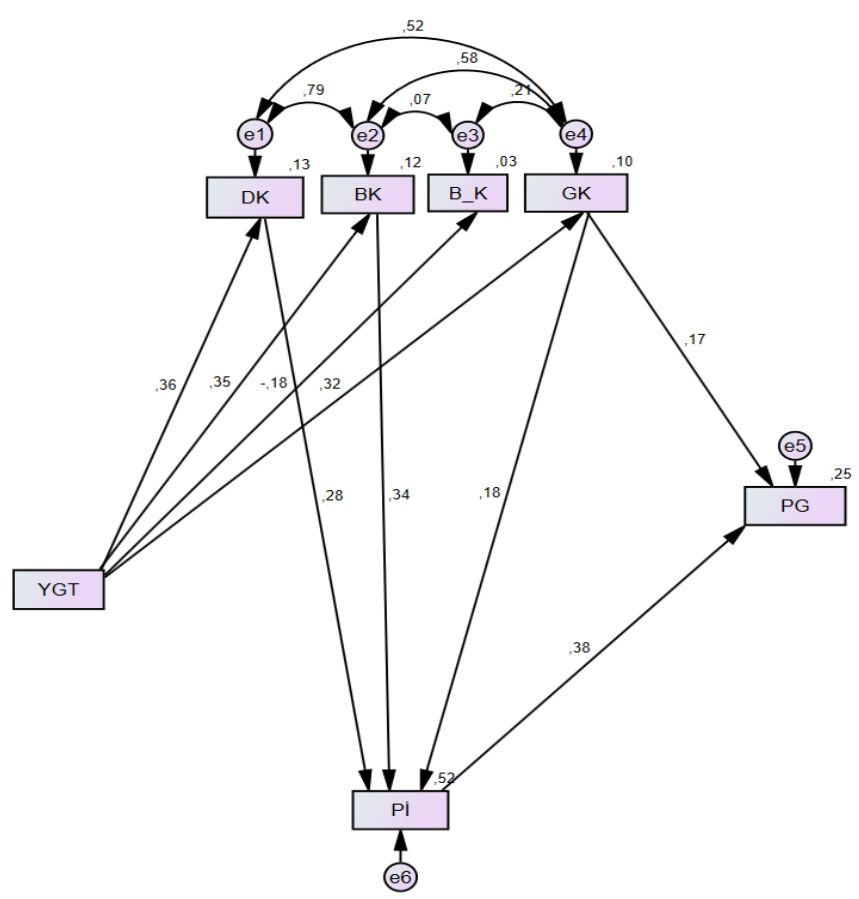

YGT: Yumuşak güç türleri, DK: Destek kültürü, BK: Başarı kültürü, B_K:

Bürokratik kültür, GK: Görev Kültürü, Pi: Psikolojik iklim, PG: psiklojik güçlendirme.

Şekil 2 Ölçüm modeli

Şekil 2'ye göre; yumuşak güç türleri, destek kültürünü, başarı kültürünü ve görev kültürünü olumlu yönde etkilerken, bürokratik kültürü olumsuz yönde etkilemektedir. Yumuşak güç türleri ile destek kültürü, başarı kültürü ve görev kültürü birlikte, psikolojik iklimi olumlu yönde etkilemektedir. Bürokratik kültür, psikolojik iklimi etkilememektedir. Yumuşak güç türleri ile görev kültürü, yumuşak güç türleri ile destek kültürü, başarı kültürü, görev kültürü ve psikolojik iklim birlikte, psikolojik güçlendirmeyi olumlu yönde etkilemektedir.

Sonuç ve Tartışma: Ulaşılan ölçüm modeline göre; okul müdürlerinin yumuşak güç kaynakları psikolojik güçlendirmeyi olumlu yönde etkilerken; sert güç kaynaklarının psikolojik güçlendirmeyi etkilemediği belirlenmiştir. Yumuşak güç kaynakları görev odaklı, başarı odaklı ve destek odaklı kültürleri olumlu yönde etkilerken; bürokratik kültürü olumsuz etkilediği tespit edilmiştir. Sert güç kaynaklarının okulun kültürel boyutlarını etkilemediği bulunmuştur. Yumuşak güç kaynakları ise psikolojik iklimi olumlu yönde etkilerken; sert güç kaynaklarının psikolojik iklimi etkilemediği görülmüştür. Başarı odaklı ve görev odaklı kültürün psikolojik güçlendirme üzerinde olumlu etkileri olsa da bürokratik kültür ve destek odaklı kültürünün psikolojik güçlendirmeyi etkilemediği sonucuna ulaşılmıştır. Başarı odaklı kültür, görev odaklı kültür ve destek odaklı kültür psikolojik iklimi olumlu yönde etkilerken; bürokratik kültürün psikolojik iklimi etkilemediği saptanmıştır. Ayrıca, psikolojik iklimin psikolojik güçlendirmeyi olumlu yönde etkilediği belirlenmiştir. Ancak, tüm değişkenler modele eklendiğinde, okul müdürlerinin güç kaynaklarının okul kültürü yoluyla psikolojik iklimi etkilediği görülmüştür. Benzer şekilde, okul müdürlerinin güç kaynakları hem okul kültürü hem de psikolojik iklim yoluyla ögretmenlerin psikolojik güçlendirme düzeylerini etkilediği belirlenmiştir. Çünkü okul müdürlerinin güç kaynaklarl, okul kültürü, psikolojik iklim ve psikolojik güçlendirme değişkenleri tek tek analiz edildiğinde, güç kaynakları diğer değişkenleri farklı düzeylerde etkilemektedir. Bununla birlikte, örgütün tüm işleyişini ve çalışanların davranışlarını etkileyen okul kültürü gibi güçlü bir değişken modele eklendiğinde, okul müdürlerinin güç kaynaklarının psikolojik iklim ve psikolojik güçlendirme üzerindeki doğrudan etkisinin ortadan kalktığı tespit edilmiştir. Okul müdürlerinin yumuşak güç kaynaklarının, okul kültürü aracılığıyla psikolojik iklimi ve psikolojik güçlendirmeyi etkilediği ortaya çıkmıştır. Bu sonuç aslında okul kültürünün okullarda ne kadar etkili olduğunu bize bir kez daha kanıtlamıştır. 